\title{
The Birth of Biopower in Eighteenth-Century Germany
}

\author{
CLAUDIA STEIN*
}

Keywords: Bavaria; Biopolitics; Biopower; Cameralism; Enlightenment; Michel Foucault; Optimum Population Trust; Johann Anton von Wolter

In April 2009, Sir David Attenborough, the respected face and voice of British natural history programmes for more than fifty years, became the patron of a new charity, the Optimum Population Trust (OPT), an organisation campaigning to limit the world's population. His reason for accepting the honour, he confessed to The Times, was that he was terribly worried about the dramatic increase of the world's population and the effect it was having on the quality of human life throughout the world:

There are three times as many people in the world as when I started making television programmes only a mere fifty-six years ago. It is frightening. We can't go on as we have been. We are seeing the consequences in terms of ecology, atmospheric pollution and in terms of the space and food production. ${ }^{1}$

The chairman of OPT, Roger Martin, was more than delighted to have the famous naturalist on his side and rejoiced that Attenborough's impact as patron was simply 'magnificent. . . because he is so widely trusted. He has decency, authority and wisdom and he sees the big picture, which, frankly, rather few people do'. 2

Curiously, Attenborough did not feel disturbed by the OPT's eugenic slogan 'Stop at Two'. But, then, what could a policy of 'only-two-children' mean to a 76-year-old father of two? OPT makes no secret of what 'Stop at Two' involves. As its website explains:

Unless we all do something, worldwide, there are going to be another 2.4 billion people on the planet by 2050. Having a smaller family - just one or two children instead of three or more - helps to reverse population growth. And by reversing population growth, we'd be taking another green step towards environmental survival for all. ${ }^{3}$

Just below this statement there is a box which, if ticked, commits the visitor to promise that 'I'm going to try not to have more than two children'! It is not clear if OPT intends to gather statistics on those who keep or break their promises.

(C) Claudia Stein, 2011.

* Dr Claudia Stein, Director, Centre for the History of Medicine, Warwick University, Coventry CV4 7AL, UK. Email: claudia.stein@warwick.ac.uk

\footnotetext{
1 'David Attenborough to be Patron of Optimum Population Trust', The Times, 14 April 2009, online: http://www.timesonline.co.uk/tol/news/environment/ article6087833.ece, accessed 27 January 2011.
}

\footnotetext{
2 'David Attenborough: In the Beginning', The Telegraph, 29 October 2010, online: <http://www. telegraph.co.uk/culture/tvandradio/8090747/DavidAttenborough-in-the-beginning.html $>$, accessed 27 January 2011.

3 'OTP's Stop At Two - Make a Difference!', $<$ http://www.optimumpopulation.org/stopattwo. html $>$, accessed 27 January 2011.
} 


\section{Claudia Stein}

Most of the journalists who reported on Attenborough's new role shared his fear of overpopulation and fully endorsed his call for reproductive self-control. ${ }^{4}$ None reminded their readers of the often-disastrous consequences of such 'solutions' in the past (and, indeed, in the present). ${ }^{5}$ At most, The Times online correspondent for 'Poverty and Development' noted that Attenborough's fears were not entirely new; they had occupied Western minds and emotions since at least the late eighteenth century. ${ }^{6}$ It was another English man, The Times correspondent proudly submitted, the Reverend Thomas Robert Malthus (1766-1834) in his An Essay on the Principle of Population (1798), who first formulated the relationship between overpopulation and the scarcity of natural resources. And it was thanks to Malthus that people began to believe that 'the power of population is indefinitely greater than the power in the earth to produce subsistence for man'?

Ripped out of context, Malthus' famous equation resonates nicely with the worries expressed by Attenborough \& Co. Indeed, the late eighteenth-century parson of political economy comes to speak perfectly to our fearful 'global times', and in English at that! Through Malthus the linkage between population (control) and national prosperity becomes as obvious and 'natural' as the moral warrant to command individual reproductive 'responsibility' in the face of 'pressures on global resources'. If we dig deeper, however, as many historians have, the equation is less tidy than it seems. When Malthus wrote, the very idea of 'population' had yet to be firmly established as a tool of political practice. Political philosophers and economic theorists had still to convince governments, savants, and the literate public of the value of collecting numbers, and of the 'utility' of those statistics for, say, facilitating comparisons between states - let alone applying them to the control and management of population(s). ${ }^{8}$ In fact, the essential

\footnotetext{
${ }^{4}$ If Attenborough is criticised at all for his support of the OPT it is because of his belief in overpopulation as a 'fact'. Several commentators have pointed out that the size of the world's population is still in dispute. For a rare but pointed critique that goes to the heart of the matter excessive consumption on the part of rich countries eating up the world's resources - see the interview with the environmentalist journalist Fred Pearce; Matilda Lee, 'Fred Pearce: Overpopulation Worries are a Potentially Racist Distraction', The Ecologist, 2 February 2010, online: <http://www.theecologist.org/ Interviews/409152/fred_pearce_overpopulation _worries_are_a_potentially_racist_distraction.html >, accessed 27 January 2011. See also his recent monograph, Peoplequake: Massmigration, Ageing Nations and the Coming Population Crash (London: Transworld Publishers, 2010).

${ }^{5}$ See Susan Greenhalgh, Just One Child: Science and Policy in Deng's China (Berkeley: University of California Press, 2008); Gunnar Broberg and Nils Roll-Hansen (eds), Eugenics And the Welfare State: Sterilization Policy in Demark, Sweden, Norway, and Finland (Ann Arbor: Michigan State University Press, 2005); and Mark B. Adams (ed.), The Wellborn Science: Eugenics in Germany, France, Brazil, and Russia (New York: Oxford University Press, 1990).
}

\footnotetext{
6 'David Attenborough to be Patron of Optimum Poulation Trust', op. cit. (note 1).

${ }^{7}$ Thomas Robert Malthus, An Essay on the Principle of Population [1789] (repr. Oxford: Oxford University Press, 1993), Chapter I, p. 13; also Chapter VII, p. 61; see also, Frank W. Elwell, A Commentary on Malthus's 1798 Essay on Population as Social Theory (Lewiston: Mellon Press, 2001).

${ }^{8}$ The term 'statistics' did not come into widespread use until the second and third decade of the nineteenth century; see Theodore M. Porter, The Rise of Statistical Thinking, 1820-1900 (Princeton: Princeton University Press, 1986); Stephen M. Stigler, The History of Statistics: The Measurement of Uncertainty before 1900 (Cambridge, MA: Belkam Press of Harvard University Press, 1986). For recent work in this area relating to England and France, see Andrea A. Rusnock, Vital Health: Quantifying Health and Population in Eighteenth-Century England and France (Cambridge: Cambridge University Press, 2002); and for the discussion centred on the German territories, see Martin Fuhrmann, Volksvermehrung als Staatsaufgabe? Bevölkerungs- und Ehepolitik in der deutschen politischen und ökonomischen Theorie des 18. und 19. Jahrhunderts (Paderborn: Ferdinand Schöningh, 2002).
} 


\section{The Birth of Biopower in Eighteenth-Century Germany}

feature of the modern capitalistic nation state in relation to population (which appears so 'natural' to Attenborough and the supporters of the OPT) was only in the making when Malthus wrote, and indeed was hugely dependent upon his writings.

My current project, 'The Birth of Biopower in Eighteenth-Century Germany', seeks to open up this 'making' by drawing on Foucault's concept of 'biopower', with its poles of individual health and the health of populations. It focuses on the Electorate of Bavaria, which was ruled by the Wittelsbach family from their large and splendid court at Munich. Bavaria was the second largest German-speaking land in the Holy Roman Empire, and one of the major political forces in Europe. My study explores how concerns with the individual wellbeing of Bavarian subjects and the prosperity of the population as a whole became integral to the priorities of those governing Bavaria. These concerns, in turn, were fed by the emergent themes of Enlightenment medicine, philosophy, politics and economics - subjects, that scholars most often discuss in isolation, and rarely ever in relation to 'sovereign power', the concept that Foucault himself tended to juxtapose with 'biopower'.

Foucault coined the terms 'biopower' and 'biopolitics' in the late 1970s in order to account for the successful rise of the concept of population control in the course of the seventeenth and eighteenth centuries. ${ }^{9}$ He argued that it was part and parcel of a whole new approach to power then emerging in all European countries that focused on the control of the human body:

I mean a number of phenomena that seem to me to be quite significant, namely, the set of mechanisms through which the basic biological features of the human species became the object of a political strategy, of a general strategy of power, or, in other words, how, starting from the 18th century, modern Western societies took on board the fundamental biological fact that human beings are a species. This is what I have called biopower. ${ }^{10}$

When these new techniques of political power first emerged in the eighteenth century they rivalled and complemented older modes of power, traditionally centred entirely on the persona of the ruler. Unlike 'biopower', which aimed both at disciplining the individual and regulating populations, 'sovereign power' was repressive and intermittent. It aimed at control through punishment and operated in response to certain sets of circumstances through specific and identifiable agents. ${ }^{11}$ By the eighteenth century, most European governments were moving from sovereign power to biopower, inventing

\footnotetext{
${ }^{9}$ The Italian philosopher Roberto Esposito explained the difference between the two terms 'biopower' and 'biopolitics' as follows: 'By the first is meant a politics in the name of life and by the second a life subjected to the commands of politics'. See Roberto Esposito, Bios: Biopolitics and Philosophy (Minneapolis MN: University of Minnesota, 2008), 15. For Foucault's discussion see, for example, Michel Foucault, The Birth of Biopolitics: Lectures at the College de France 1978-1979 (Basingstoke: Palgrave Macmillian, 2008); Michel Foucault, Security, Territory, Population: Lectures at the College de France 1977-78 (Basingstoke: Palgrave Macmillian, 2007);
}

Michel Foucault, The History of Sexuality, Volume 1 [1977] (repr. London: Penguin, 1998), 140. On the use of 'biopower' in contemporary intellectual debate in philosophy, social and political sciences, see Roger Cooter and Claudia Stein, 'Cracking Biopower', History of the Human Sciences, 23 (2010), 109-28.

${ }^{10}$ Foucault, Security, Territory, Population, ibid., 1-4.

${ }^{11}$ Foucault sketched out the characteristics of sovereign power in the first two chapters of his famous work, Discipline and Punish: The Birth of the Prison (Harmondsworth: Penguin Books, 1982), 3-69. 


\section{Claudia Stein}

new ideas and practices that linked the health of individuals and populations within territorial systems for economic and political security. ${ }^{12}$ 'Public health' (as it would come to be known in the nineteenth century), sexuality, and concerns with the wellbeing and longevity of individuals became their target in relation to the collective prosperity of the political whole.

In the German-speaking territories, of which there were nearly four hundred in the eighteenth century, this development was particularly pronounced, attached as it was to the then emergent 'science of government' known as 'cameralism' (the German counterpart of French mercantilism). ${ }^{13}$ Cameralism, which was as much an economic theory as a political practice, aimed at mobilising all the available resources of a territory and its population in the service of a common good. ${ }^{14}$ Thus it concentrated on the growth of economic production and necessarily a strong productive work force. Central to it was the establishment of an apparatus that would ensure the subjection of the productive individual and the population as a whole. ${ }^{15}$ For this, as well as for the 'happiness' of the fatherland, the practice of medicine and 'public health' were crucial. As historians of medicine have pointed out, in the course of the eighteenth-century treatises on 'medical police' (medicinische Policey) proliferated. ${ }^{16}$ In the German literature, this 'policing' (a term with much wider meaning than today) is usually written within the narrative of 'the rise of public health', 'the professionalisation of medicine', and the history of 'medicalisation', and always in reference to the process of state formation. ${ }^{17}$ What this emphasis loses sight of, however, is the fact that these biopolitical efforts for the care of the individual and social body were actually conducted within absolutist states. Cameralism, indeed to the frustration of many of its would-be instigators, was compelled

\footnotetext{
${ }^{12}$ Michel Foucault, 'The Birth of Social Medicine', in idem, Power, J.D. Faubion (ed.), (New York: The New Press, 2000), 38.

${ }^{13}$ Foucault attributed the manifestation in the German-speaking lands to the lack of any unitary state structure (in contrast to France and England), the relatively small size of each political entity, and their close proximity, which encouraged perpetual conflict and confrontation: ibid., 137-8. Recently, the sociologist Patrick Carroll has tried to demonstrate that eighteenth-century England did indeed develop successful practices of medical policing: 'Medical Police and the History of Public Health', Medical History, 46 (2002), 461-94.

${ }^{14}$ On cameralism see, Keith Tribe, Governing Economy: The Reformation of German Academic Discourse (Cambridge: University of Cambridge Press, 1988); David F. Lindenfeld, The Practical Imagination: The German Sciences of State in the Nineteenth Century (Chicago: University of Chicago Press, 1997). However, there is much disagreement over the actual effectiveness of Cameralistic policies. See, for example, Volker Bauer, Hofökonomie: Der Diskurs über den Fürstenhof in der

Zeremonialwissenschaft, Hausväterliteratur und Kameralismus (Vienna: Böhlau, 1997); and Andre Wakefield, The Disordered Police State: German
}

Cameralism as Science and Practice (Chicago: Chicago University Press, 2009).

${ }^{15}$ Foucault, 'The Politics of Health in the Eighteenth Century', in idem, op. cit. (note 12), 96.

${ }^{16}$ For a solid overview see Caren Möller, Medizinalpolizei: Die Theorie des staatlichen Gesundheitswesens im 18. und 19. Jahrhundert (Frankfurt: Vittoria Klostermann, 2005).

${ }^{17}$ See, for example, Martin Dinges, 'Medicinische Policey zwischen Heikunde und "Patienten" (1750-1830)', in Karl Härter, Policey und frühneuzeitliche Gesellschaft (Frankfurt: Vittorio Klostermann, 2000), 263-95; Mary Lindemann, Health and Healing in the Eighteenth Century (Baltimore: John Hopkins University Press, 1996); Francisca Loetz, Vom Kranken zum Patienten: "Medikalisierung" und medizinische Vergesellschaftung am Beispiel Badens 1750-1850, (Stuttgart: Steiner Verlag, 1993); Ute Frevert, Krankheit als politisches Problem (1770-1880) (Göttingen: Böhlau, 1984). For the openness of the term 'policey', which described the ensemble of mechanisms to ensure political order, see Michael Stolleis, Geschichte des öfentlichen Rechts in Deutschland, Bd.1: Reichspublizistik und Policeywissenschaft 1600-1800 (Munich: C.H. Beck, 1988), 369-70. 


\section{The Birth of Biopower in Eighteenth-Century Germany}

to take as its essential object the might of the sovereign who sought not so much to increase the wealth of the country as a whole, as to facilitate his or her personal wealth accumulation, and hence the military might with which to carry out sovereign policies. ${ }^{18}$ Moreover, the instruments that cameralism used - laws, decrees and regulations - were the traditional weapons of sovereignty. Cameralism under absolutist rule therefore points to something that Foucault mentioned only in passing - that the emergence of 'biopower' was not a straightforward linear process replacing sovereign power, but rather, a matter of struggle and contestation within the eighteenth-century absolutist state.

My project aims at investigating these struggles through the example of the Electorate of Bavaria. One of my central claims is that in Bavaria the new technologies of biopower were 'born' at court, the centre of sovereign power. By way of illustration, I focus on the courtier and physician, Johann Anton von Wolter (1711-87), an Enlightenment figure with great enthusiasm for cameralist policy and medical policing, and who regarded his profession as central to the economic welfare of the Bavarian state. ${ }^{19}$ Von Wolter was also a clever politician who succeeded in serving the last two Bavarian Wittelsbach Electors, Maximilian III Joseph (1727-77), and Karl Theodor (1724-99) for almost thirty years - a rare achievement in a micro culture of mischievous gossip and intrigue. As the first physician (protomedicus) of the country, von Wolter was responsible for the personal health of the Elector himself and his family, and for structuring and organising medicine and healthcare in the Electorate at large. In a world in which political power was measured through proximity to the ruler, von Wolter's influence was considerable, and he used it both to advance the idea of a medical police, and for specific reforms in midwifery, military medicine, and the control of epidemics. $\mathrm{He}$ also used it for the reform of agriculture and food production as sources for the health of the population. ${ }^{20}$

Like other cameralist administrators, von Wolter felt the straightjacket of absolutist rule. Chronically cash-trapped because of their involvement in the European wars of the time, Maximilian III Joseph and Karl Theodor were neither keen nor able to provide steady and generous support for von Wolter's often seemingly (to them) rather grand ideas. ${ }^{21}$ For example, his endorsement of smallpox vaccination was met with outright

\footnotetext{
${ }^{18}$ See the discussion in Michel Foucault, 'Governmentality', in idem, op. cit. (note 12), 214; for the only German contribution, to my knowledge, which uses Foucault's concept of biopower to analyse health in the eighteenth century, see the work of the sociologist Christian Barthel, Medizinische Polizei und Aufklärung: Aspekte des öffentlichen Gesundheitsdiskurses im 18. Jahrhundert (Frankfurt: Campus, 1989).

${ }^{19}$ Revealing in this regard is von Wolter's lecture given on the occasion of the Elector Maximilian III's birthday in 1768: see Bayerische Akademie der Wissenschaften, Akademische Reden, Bd. 1762-1770, Wolter (1768), 12 October 1768. On von Wolter, see Elisabeth Barbara Peer, Johann Anton von Wolter 1711-1787: Kurfürstlicher Leibarzt und Protomedicus im aufgeklärt-absolutistischen Bayern (dissertation, Munich 1977); and Claudia Stein,
}

\begin{abstract}
'Johann Anton von Wolter (1711-87): A Bavarian Court Physician Between Aufklärung and Reaktion?, in Ole Peter Grell and Andrew Cunningham (eds), Medicine and Religion in Enlightenment Europe (Aldershot: Ashgate , 2007), 173-94.

${ }^{20}$ For an overview of the impact of enlightened ideas on the sciences and medicine in absolutist Bavaria see Andreas Kraus, Die naturwissenschaftliche Forschung an der Bayerischen Akademie der Wissenschaften 1759-1806 (Munich: C.H. Beck, 1978); also Luthger Hammerstein, 'Die Aufklärung in Wissenschaft und Gesellschaft, in Max Spindler and Andreas Kraus, Handbuch der Bayerischen Geschichte, Vol. II, 2nd edn (Munich: C.H. Beck, 1988), 1135-97.

${ }^{21}$ For eighteenth-century Bavarian politics see, for example, Manfred Rau, Verwaltung, Stände und Finanzen: Studien zu Staatsaufbau und
\end{abstract}




\section{Claudia Stein}

opposition from Maximilian III Joseph (who, with poetic justice, fell victim to the disease in 1777). In what follows, I want to turn to another example of von Wolter's activities, which was successfully implemented, the regulation and reform of midwifery. I will briefly sketch how his life as a courtier was crucial to the development and implementation of such reform.

Von Wolter's interest in midwifery was rooted in the greatest political catastrophe to face Bavarian politics in the second half of the eighteenth century, namely, the prospect of no heir to the throne. Neither the Electoral spouse, Maria Anna of Saxony (172897), nor Maria Anna of Palatine (1722-90), the wife of Duke Clemens (1722-70), the Elector's direct cousin (and second in line of dynastic heritage), were able to produce offspring (despite several successful pregnancies). Von Wolter, during the first decade of his appointment at court was deeply involved in the medical care of these two women. Among other things, this put him in continuous correspondence with major European specialists in midwifery. It also entailed extended visits to various restorative spas. He turned the situation to his advantage, exploiting the issue of the succession to convince the Elector Maximilian III Joseph to innovate by appointing several male French accoucheurs to the Munich court. ${ }^{22}$ He also established a generous grant system to enable aspiring Bavarian surgeons to train at the famous midwifery school of Johann Jakob Fried (1689-1769) in Strasbourg before taking up appointments back in their home country. When it became increasingly clear that the Electoral couples would remain childless and the courtly services of the male accoucheurs were no longer required, von Wolter managed to convince Maximilian III Joseph to supply them with official titles and appointments at key administrative centres in Bavaria. Once dispersed, events took their own course. Since it was not easy for the accoucheurs to survive once they were cut off from the professional and social amenities of the court (they were often irregularly paid, and faced not only the hostility of local populations, but that of competing medical men and midwives) they devised new means of surviving. Many of them published books on midwifery or other aspects of medical police for the glory and economic benefit of the fatherland. Some opened midwifery schools, which, once they were officially recognised by the Collegium Medicum (which was presided over by von Wolter), began training local midwives and surgeons in the latest scientific theories and practices of midwifery. By the end of the eighteenth century no one in Bavaria could practice midwifery without having passed through one of these schools. Thus, directly and indirectly, von Wolter succeeded in turning midwifery into a centralised and state-controlled system - ironically, as the Wittelsbach family line died out in 1799 for want of issue. ${ }^{23}$ Von Wolter's immediate concern for

Staatsentwicklung Bayerns unter dem späten Absolutismus (Munich: C.H. Beck, 1988); and Hans Rall, Kurfürst Karl Theodor: Regierender Herr in sieben Ländern (Mannheim: B.I.

Wissenschaftsverlag, 1993); and now Michael Schaich, Staat und Offentlichkeit im Kurfürstentum Bayern der Spätaufklärung (Munich: C.H. Beck, 2001).

${ }^{22}$ For an example of the substantial literature on midwifery in eighteenth-century Germany, see, Hans-
Christoph Seidel, Eine neue "Kultur des Gebärens": Die Medikalisierung von Geburt im 18. und 19. Jahrhundert in Deutschland (Stuttgart: Steiner, 1998).

${ }^{23}$ The marriage of the Elector Karl Theodor and his wife Elisabeth Augusta of Palantine (Duchess Maria Anna's sister) was also childless. For the political drama involved, see Stefan Mörz, Die Letzte Kurfürstin: Elisabeth Augusta von der Pfalz, die 


\section{The Birth of Biopower in Eighteenth-Century Germany}

the continuation of sovereign power conveniently permitted him to develop and exercise new practices of biopower that, ever after, would target the individual bodies of Bavarian subjects and regulate the population at large. Thus - but not without immense struggle - did sovereign power give issue to the new technologies of biopower.

This is not to say, however, that biopower put flight to sovereign power once and for all. The struggle between sovereign power and biopower did not end in the eighteenth century. Indeed, as the Italian political philosophers Giorgio Agamben and Roberto Esposito have powerfully argued, the struggle is ongoing. ${ }^{24}$ Agamben and Esposito - both deeply influenced by Foucault's original idea - reflect on the relationship between sovereign power and biopower post-Second World War as a phenomenon hidden behind the political rhetoric of liberal and neoliberal states. To be sure, the contest appears in different guises than it did in eighteenth-century Bavaria - above all, and most darkly, in Nazi Germany. ${ }^{25}$ What remains the same since the eighteenth century, however, is that the struggle between these different exercises of power on the bodies of individuals and populations is conducted in the name of economic prosperity. The Bavarian story of the struggle helps to make this clear. From this perspective, the OPT's rhetoric is nothing but another version of the same old struggle.

Gemahlin Karl Theodors (Stuttgart: W. Kohlhammer, 1997), 59-77.

${ }^{24}$ Giorgio Agamben, Homo Sacer: Sovereign Power and Bare Life (Stanford, CA: Stanford University Press, 1998); Esposito, op. cit. (note 9). On recent works on biopower and sovereign power see also Majia Holmer Nadesan, Governmentality, Biopower, and Everyday Life (New York: Routledge, 2008).

${ }^{25}$ Esposito, ibid., 15. 